\title{
MEMÓRIA E CARÁTER: ARISTÓTELES E A HISTÓRIA PESSOAL*
}

\author{
Pierre-Marie Morel \\ École Normale Superieur de Lyon
}

\begin{abstract}
For Aristotle, memory is not the conservation of the traces of the past and taking them again as objects only. His treaty "On memory and reminiscence" examines in a general trend the role of images in the exercise of thinking. Aristotle describes the process of reminiscence or remembrance, analyzing the voluntary organization of mental representations as well as its involuntary and pathological ways. At the same time, he explains both the way through which man can be the agent of his own representations and the principle of the relations one makes. As far as memory is concerned, Aristotle deals with critical questions for the definition of psychic states, for epistemology and for the conception of the self or personal identity. The analysis of memory and reminiscence drives us to a reevaluation of the aristotelic concept of character $(\hat{\eta} \theta \circ \varsigma)$, turning it into the basis and the agent of a personal history that cannot be abstracted from its psychophysical conditions.
\end{abstract}

Keywords: memory, character, reminiscence, personal identity.

Resumo: Para Aristóteles, a memória não consiste somente em conservar os traços do passado e tomá-los novamente por objetos. 0 tratado Da memória e da reminiscência examina mais geralmente 0 papel das imagens no exercício do pensamento. Ele descreve o processo de reminiscência ou rememoração, e trata assim da organização voluntária das representações mentais como de seus encaminhamentos involuntários e patológicos. Correlativamente, ele explica em que sentido o homem pode ser agente de suas próprias representações e o princípio de suas associações. Aristóteles aborda, por conseguinte, a propósito da memória, questões fundamentais para a definição dos estados psíquicos, para a teoria do conhecimento, bem como para a concepção do eu ou da identidade pessoal. A análise da memória e da reminiscência conduz assim a uma reavaliação da concepção aristotélica do

\footnotetext{
* Este artigo, "Mémoire et caractère: Aristote et l'histoire personelle", foi publicado originalmente em BRANCACCI, A.; GIGLIOTTI, G. (eds.). Mémoire et souvenir. Six études sur Platon, Aristote, Hegel et Husserl. Napoli: Bibliopolis, 2006, p. 47-87. Agradecemos vivamente aos editores pela liberação do artigo para a publicação em português (com tradução de João Hobuss e Sonia Maria Schio [UFPel]).
} 
caráter ( $(\hat{\eta} \theta$ os), fazendo deste último 0 substrato e 0 agente de uma história pessoal que não pode ser abstraída de suas condições psicofísicas.

Palavras-chave: memória, caráter, reminiscência, identidade pessoal.

A memória não é somente uma atitude de conservar os traços do passado? O tratado de Aristóteles Da memória e da reminiscência ${ }^{1}$, o segundo dos Pequenos tratados de história natural (ou Parva naturalia), dá boas razões para duvidar disto. Ele trata seguramente, e de uma maneira particularmente rigorosa e original, da conservação das sensações passadas e da atualização da lembrança: os efeitos da idade ou do temperamento sobre a conservação das lembranças; de suas deformações; da consciência da lembrança enquanto tal; das associações de idéias imediatas que a suscitam. Aristóteles elabora a primeira análise explicativa e sistemática da memória, e o De memoria é, a este respeito, um texto fundador ${ }^{2}$. Entretanto, ele examina igualmente o papel das imagens no exercício do pensamento;

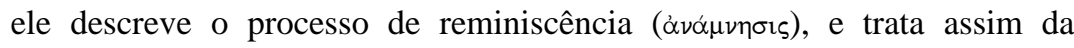
organização voluntária das representações mentais como de seus encadeamentos involuntários e patológicos. Correlativamente, ele explica em que sentido o homem pode ser o agente de suas próprias representações e o princípio de suas associações. Ele evoca entrelinhas a apropriação das lembranças, além de sua simples conservação espontânea, e coloca, de fato, a questão da cronologia pessoal, de sua continuidade, e de suas rupturas. Assim, a propósito da memória ( $\mu \nu \eta \eta \eta \eta)$, longe de limitar-se ao processo de conservação, Aristóteles aborda questões fundamentais para a definição dos estados psíquicos, para a teoria do conhecimento, bem como para a concepção do eu ou da identidade pessoal, ou seja, em termos mais aristotélicos, do caráter (i̊日os).

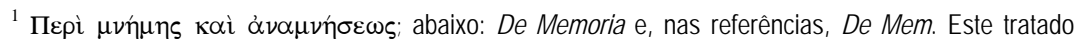
ocupa as linhas 449b 4-453 b 11 da edição de referência (edição Bekker da Academia de Berlim, 18301871) das obras de Aristóteles.

${ }^{2}$ O Tratado da alma (ou De Anima), no que lhe concerne, não diz praticamente nada da memória. No De An., III, 3, 427 b 19, é feita uma alusão aos exercícios mnêmotécnicos, como é questão no segundo capítulo do De Memoria. Em III, 5, 430 a 23-25, Aristóteles explica muito rapidamente os defeitos da memória pelo fato de que 0 intelecto passivo esta sujeito à corrupção.
} 
É verdade que, em Aristóteles, a questão da relação com o passado na constituição do caráter individual só é abordada ocasionalmente, e sem implicações manifestas para a doutrina da alma. Esta, tal como exposta por Aristóteles - no De anima e no Parva naturalia -, não diz nada de explícito sobre o caráter individual. As Éticas, que são mais instrutivas a este respeito, dão, entretanto, pouca atenção ao papel que a consideração do passado seria suscetível de desempenhar na conduta moral e na busca da felicidade. Embora a disposição virtuosa pressuponha um tipo de retenção dos efeitos produzidos pelas ações anteriores, como veremos mais adiante, Aristóteles não faz grande caso do uso consciente das lembranças pessoais no domínio prático, como também não parece crer nas especulações platônicas sobre a relação entre a maneira atual de viver e a sorte que nos seria reservada post mortem. Ele critica, por conseguinte, sem rodeios, o argumento que Sólon opõe a Cresus, convencido de ser o mais feliz dos homens: segundo Sólon, seria necessário alcançar o termo de sua vida para poder afirmar, na lembrança das ações passadas, e uma vez preservado das vicissitudes da sorte, que se foi feliz ${ }^{3}$. Para Aristóteles ${ }^{4}$, é absurdo de se dizer que alguém é feliz não porque o é atualmente, mas porque o foi anteriormente: não se pode dizer de alguém que é feliz se está morrendo, na medida em que não se está mais em situação de agir; ora, a felicidade consiste em um certo tipo de atividade, a ação conforme à virtude ${ }^{5}$. A atualidade dos motivos que se oferecem à deliberação relega ao segundo plano a experiência do passado.

Como veremos, a análise da memória é muito mais esclarecedora a este respeito. Não é, verdadeiramente, o conhecimento do passado enquanto tal, do qual a memória seria tão somente o meio ou o instrumento, que nos coloca sobre a via da individualidade pessoal, mas a memória ela mesma enquanto processo específico ${ }^{6}$. Esta não é simplesmente uma, dentre outras,

\footnotetext{
${ }^{3}$ Heródoto, Hist., I, 30-33.

${ }^{4}$ EN, I, 11, 1100 a 32-34.

${ }^{5}$ Sobre a definição da felicidade como atividade, ver C. Natali, La saggezza di Aristotele. Napoli: Bibliopolis, 1989, p. 307-313; P.-M. Morel, Aristote. Une philosophie de l'activité. Paris: Flammarion, 2003, p. 182-214.

${ }^{6}$ Aristóteles não afirma, com efeito, que a memória é "pessoal" a partir do momento em que ela se refere a um passado pessoal, à lembrança direta de uma experiência em primeira pessoa a partir da qual perceberemos 0 objeto do qual haverá mais tarde lembrança. J. Annas, "Aristotle on memory and the self". In: NUSSBAUM, M. C. e RORTY, A. (eds.). Essays on Aristotle's De Anima. Oxford: Clarendon Press, 1992, p. 279-311, estima, entretanto, poder descobrir no De Memoria uma distinção
} 
modalidades do conhecimento em geral. É um processo mental particular, dotado de uma relativa autonomia de funcionamento em relação às outras operações cognitivas, mesmo se a lembrança nasce do traço deixado por uma sensação ${ }^{7}$. Antes de ser, eventualmente, uma questão existencial, a relação ao passado depende, com efeito, da "psicologia", entendendo este termo como a parte da filosofia natural que trata da alma enquanto um primeiro princípio imanente de um composto de alma e corpo. O estudo da memória desenvolve-se, então, no quadro de uma investigação sobre os estados comuns à alma e aos corpos. É isto que se situa a originalidade e a força da teoria aristotélica da memória: como todo $\pi \dot{\alpha} \theta$ os - "afecção" ou "acidente" - do composto vivente, ou ainda: uma forma incorporada ou uma "razão na matéria"8. A memória tal como Aristóteles define é, por conseguinte, uma atividade incorporada, e esta incorporação lhe é essencial. A memória é, ao mesmo tempo, uma operação cognitiva e um estado orgânico.

Correlativamente, o interesse de Aristóteles pela memória não para no exame de um fato de consciências, e isto por duas razões. Em primeiro lugar, o trabalho da memória deixa lugar a disfunções das quais não temos a noção plena nem o controle. Em segundo lugar, o funcionamento regular da memória, enquanto que depende de uma série de fatores orgânicos, e não somente de fatores intencionais, escapa em parte à consciência clara que podemos ter de nossos próprios estados. Em usando nossa memória, nós somos os agentes de uma atividade mental que nos é própria e da qual, entretanto, não conhecemos totalmente as disfunções nem as condições.

As questões, seguramente, não se limitam à psicologia. A concepção aristotélica da memória permite, especialmente, responder a questões epistemológicas. A memória subentende o processo indutivo e faz assim o

implícita entre memória pessoal e memória não pessoal. Esta última concerniria aos casos onde não lembramos mais de ter aprendido aquilo do qual nos lembramos. Aristóteles indica simplesmente que "a

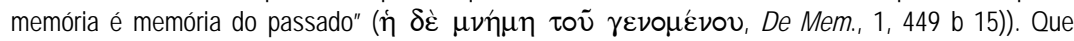
conheçamos atualmente ou não as circunstâncias originais da formação da lembrança, não muda nada no que diz respeito a esta definição.

${ }^{7} \mathrm{~A}$ memória apreende 0 que é passado enquanto passado, por oposição à representação do que é presente ou futuro. Ver De Mem., 1, 449 b 9-45.

${ }^{8} \mathrm{De} A n ., \mathrm{I}, 1,403$ a 25. Desde o começo do tratado que ele lhe consagra, Aristóteles indica que a

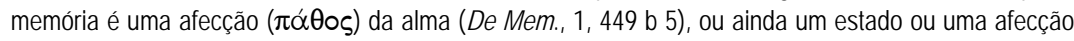

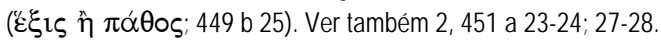


laço entre percepção e intelecção, como mostra o último capítulo dos Segundos analíticos (II, 19), texto canônico da teoria aristotélica da ciência, já que ele expõe as condições de apreensão dos primeiros princípios. É

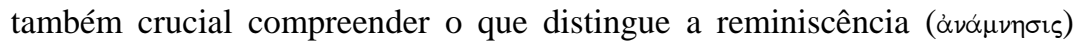
descrita na segunda parte do De memoria, da reminiscência tal qual Platão a concebe: para Aristóteles, experimentar a reminiscência não é encontrar o conhecimentos das formas inteligíveis, além do sensível, mas "apreender novamente" um conhecimento científico ou uma sensação, ou uma lembrança ${ }^{9}$. Assim, a $\alpha \nu \alpha \dot{\alpha} \mu \nu \eta \sigma ı \varsigma$ não discrimina mais entre os graus de veracidade, ou entre os estatutos ontológicos respectivos do inteligível e do sensível. Do mesmo modo, ela não se distingue mais da memória no sentido em que, exercendo a reminiscência, a alma agiria "por ela mesma”, quer dizer, "separadamente do corpo"10. Não há aqui uma diferença radical entre o processo pelo qual lembramos uma figura sensível e aquele pelo qual lembramos um conhecimento científico, sendo que, nos dois casos, "a

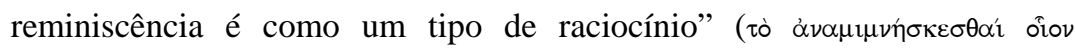

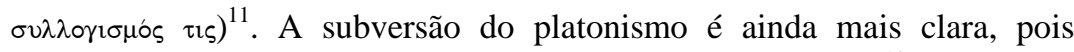
Aristóteles utiliza o mesmo termo que Platão já havia utilizado ${ }^{12}$.

Contudo, malgrado a importância das questões epistemológicas, o ponto de vista psicológico do De memoria é uma condição necessária a respeito de toda outra consideração sobre o uso metódico ou sobre a significação existencial da memória. A dificuldade que Aristóteles deve resolver torna-se dede já a seguinte: de uma parte, a formação espontânea da lembrança a partir de uma sensação anterior e as condições fisiológicas

\footnotetext{
${ }_{9}$ De Mem., 2, 451 b 2-5.

10 Platão, Filebo, 34 a-c. Isto não quer dizer que, para Platão, a reminiscência seja totalmente independente do corpo, pois ela apreende novamente o que a alma "experimentou antes com o corpo" (34 b), e então esqueceu. Ver DIXSAUT, M. "Une certaine espèce de vie (Philèbe, 34 d1-36c3)". In: DIXSAUT, M. (ed.). La fêlure du plaisir. Études sur Le "Philèbe" de Platon. Paris: Vrin, 1999, p. 252-256.

${ }_{11}$ De Mem., 2, 453 a 10.

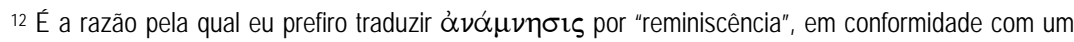
uso comumente admitido entre os tradutores franceses de Platão. Podemos preferir "rememoração" para insistir na novidade da posição de Aristóteles, mas arriscamos de esquecer que lidamos com a mesma palavra. De resto, em francês, o termo "reminiscência" se aplica sem dificuldade a imagens sensíveis ou a sentimentos. Além disto, Aristóteles usa o mesmo termo, $\mu \nu \eta ́ \mu \eta$, para designar a memória e a

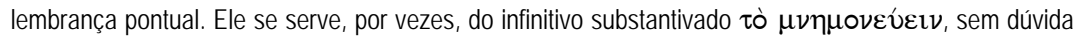
para evocar mais especificamente o exercício atual da memória, entendida como faculdade, por oposição à atitude ou à tendência. Ver neste sentido SORABJI, R. Aristotle. On memory. London: Duckworth, 1972, p. 64.
} 
da memorização implicam uma forma de passividade, e assim de extrema vulnerabilidade às vicissitudes da existência e às rupturas que elas implicam; de outra parte, a memória é uma atividade da alma, como atesta de maneira eminente o uso voluntário da reminiscência, e uma atividade constitutiva do sujeito que a exerce. É, por conseguinte, no quadro de uma psicofísica, antes de toda problemática existencial, que Aristóteles, pelo intermédio de sua teoria da memória, aborda a questão da individualidade pessoal.

\section{Uma memória incorporada}

Para compreender o alcance e as intenções do De memoria, é necessário guardar no espírito que sua proposta se insere no programa geral que governa o conjunto dos Parva naturalia. Aristóteles o expõe na primeira página do tratado Da sensação e dos sensíveis (De sensu), o primeiro deste conjunto de tratados. Ele anuncia que vai examinar as propriedades ou os estados que são "comuns, ao mesmo tempo, à alma e ao corpo, como a sensação, a memória, a impulsão, o apetite e o desejo em geral, assim como o prazer e a dor" ${ }^{, 13}$. Ele acrescenta a esta primeira lista quatro pares de proprie-dades vitais: a vigília e o sono, a juventude e a velhice, a inspiração e a expira-ção, a vida e a morte ${ }^{14}$. O estudo da memória toma lugar, então, numa vasta investigação das propriedades do composto, compreendendo sob este com-junto as funções cognitivas tanto quanto as funções propriamente vitais. A memória faz, portanto, parte das propriedades "comuns à lama e ao corpo".

Esta última expressão não é perfeitamente clara, tendo dado lugar a interpretações divergentes. $\mathrm{O}$ fato que haja $x_{s}$ comuns à alma e ao corpo pode ser entendido de duas maneiras. Em primeiro lugar, se há $x_{\mathrm{s}}$ comuns à alma e ao corpo, e se existe necessidade de enumerá-los e de identificá-los, podemos supor que há também certas entidades $y, z$, que não lhes são comuns, de modo que a alma e o corpo teriam propriedades comuns, mas também propriedades distintas. Em todo caso, é claro que se o intelecto é efetivamente separado ou separável como indica ou projeta o De anima ${ }^{15}$, a

\footnotetext{
${ }^{13}$ De sensu, 1, 436 a 6-10.

${ }^{14}$ De sensu, 1, 436 a 11-15.

${ }^{15}$ De An. I, 1, 403 a 8; III, 5, 430 a 17; 22.
} 
alma dos seres racionais possui, ou atualiza em certas circunstâncias, os estados que não são, neles mesmos, estados fisiológicos ${ }^{16}$. O problema do estatuto do intelecto na psicologia aristotélica, como se sabe, é de uma amplitude considerável e não é questão de resolver esta questão aqui. Entretanto, não é fora de propósito estando dado que o intelecto individual não se exerce sem memória. Nós teremos que retornar a isto. Em segundo lugar, a relação de "comunidade" supõe nela mesma uma dualidade, a das instâncias que têm alguma coisa “em comum”. Poderíamos, então, considerar que $x$ afeta simultaneamente, ou por analogia e sob dois aspectos diferentes $\left(x^{\prime} ; x^{\prime \prime}\right)$, duas realidades distintas. Nós deveríamos, em consequência, poder distinguir, por exemplo, a lembrança como estado físico ( $s$ '), da lembrança como estado psíquico ( $s$ ”), ou bem o estado psíquico "lembrança", de um estado físico nomeado de outro modo, que seria, por assim dizer, seu correspondente. Também os defensores da leitura "genética" ou evolucionista da obra de Aristóteles viram no uso da expressão "comum à alma e ao corpo" o sinal de uma perspectiva ainda dualista, na qual a alma e o corpo seriam duas substâncias distintas ${ }^{17}$. Os Parva naturalia, ou alguns dentre eles, deveriam, consequentemente, pertencer a um outro período que aquele em que foi redigido o livro II do De anima. Este último texto professa, com efeito, da maneira a mais firme, a indissociável unidade do composto, unidade "hilemórfica", na qual a alma é forma e princípio substancial, e o corpo vale como matéria. A alma é a enteléquia ou a realização primeira, e assim a vitalidade constitutiva, de um corpo natural, que está ele mesmo disposto - por sua constituição elementar e por sua morfologia - de maneira a ser informado, isto é, neste caso: animado $^{18}$.

O caso da memória, precisamente, mostra que a leitura dualista não se impõe de modo algum: Aristóteles não distingue entre dois estados,

${ }^{16}$ Como mostrou VAN DER EIJK, PH. "Processes and the bodily aspects of thinking". IN: KULLMANN, W; FÖLLINGER, S. (eds.). Aristotelische biologie. Intentionen, methoden, ergebnisse. "Philosophie der antike", VI. Stutgart: Steiner, 1997, p. 231-258., isto não quer dizer que os atos do pensamento não estejam ligados aos processos fisiológicos particulares. Nós o veremos analisando o processo da reminiscência.

${ }_{17}$ Para uma visão de conjunto dos argumentos em favor desta posição, ver a introdução de ROSS, D. Aristotle (a revised text with introduction and commentary). Oxford: Clarendon Press, 1995. Contra esta leitura, sobre o objeto global dos Parva naturalia e 0 estado da questão, eu reenvio à introdução de MOREL, P.-M. Aristote. Petits traités d'histoire naturelle (Parva naturalia). Paris: Flammarion, 2000.

${ }^{18}$ De $A n .$, II, 1, 412 a 3-413 a 10. 
segundo a dicotomia do psíquico e do fisiológico. Nós veremos, efetivamente, que a distinção entre a lembrança traço da sensação passada e a lembrança conside-rada como uma imagem indicativa disto do qual é lembrança não opõe a alma ao corpo, mas dois aspectos correlativos de uma mesma afecção ao mês-mo tempo psíquica e corporal. A memória é uma afeç̧ão ou uma faculdade da alma, e é o que justifica que Aristóteles se pergunte a qual parte psíquica ela pertence ${ }^{19}$, mas ela é também, e deste fato mesmo, uma afeç̧ão ou uma faculdade do composto da alma e do corpo. Então, ela é igualmente corporal.

Aristóteles o assinala, explicitamente, tanto a propósito da memória em sentido estrito, ou da lembrança, quanto a propósito da reminiscência.

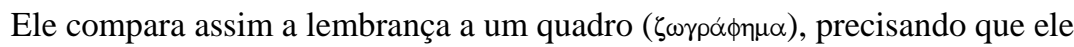

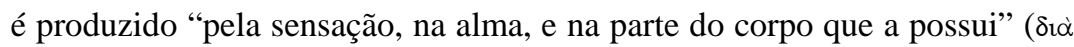

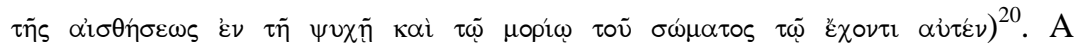
proposição apresenta uma dificuldade, pois há uma incerteza sobre o referente do pronome $\alpha \hat{\imath} \tau \varepsilon v$, se bem que podemos compreender seja "a parte do corpo que possui a alma”, seja "a parte do corpo que possui a sensação". A alma, rigorosamente, não está localizada em nenhuma parte do corpo, mas ela está presente em todas as suas partes e em cada uma de suas funções $^{21}$. Em todo estado de causa, a significação implícita do texto permanece a mesma: é no coração ou na sua região, o coração sendo o princípio orgânica da vida, do movimento e da sensação ${ }^{22}$, que as imagens das sensações passadas são conservadas. A lembrança é então produzida ao mesmo tempo na alma e no corpo, o que significa reafirmar que ela afeta, ao mesmo tempo, a alma e o corpo.

\footnotetext{
19 Ver as primeiras linhas do De Memoria: "no que concerne à memória, e ao fato de se lembrar, é necessário dizer o que é, qual é a causa de sua gênese, e à qual parte da alma pertence esta afecção e o exercício da reminiscência" (1, 449 b 4-6).

20 De Mem., 1, 450 a 28-29.

${ }^{21}$ No contexto dos Parva naturalia, a situação é mais complexa, pois Aristóteles evoca várias vezes uma localização da alma no corpo. Ver De Juv. (Da juventude e da velhice), 1, 467 b 15; 4, 469 b 13-17; De Resp. (Da respiração), 8, 474 b 13 e 16, 478 a 28-30. Além disto, é manifesto que o coração - ou sua região - tem uma função preeminente na animação, porque ele constitui o primeiro intermediário, ou 0 primeiro instrumento corporal da alma. Aristóteles, consequentemente, pode querer dizer, a propósito da "parte" do corpo que possui a alma, não que esta última está localizada exclusivamente neste lugar, mas que este - a região do corpo - é o primeiro instrumento da alma e o primeiro órgão vital do organismo. Cf. P.-M. Morel, op. cit., p. 55-57.

22 Ver, por exemplo, Partes dos animais, III, 3, 665 a 11-13. Aristóteles afirma mais adiante (III, 7, 670 a 25-26) que o coração é um foyer que funciona como "a acrópole" do corpo.
} 
A propósito da reminiscência, Aristóteles afirma o seguinte:

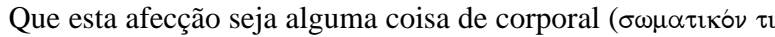

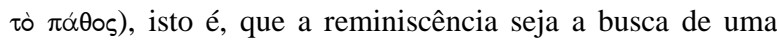
imagem nisto que é tal, nós temos uma prova pelo fato de que alguns se sentem incomodados quando não chegam a lembrar alguma coisa, malgrado um esforço de intensa reflexão $^{23}$.

Por "isto que é tal”, é necessário entender, sem nenhuma dúvida, "alguma coisa de corporal”: a reminiscência consiste em apreender novamente as imagens, materialmente conservadas como traços das operações cognitivas anteriores, na região cardíaca, onde estão de algum modo estocadas. Aristóteles precisa, além disto, que aquele que experimenta

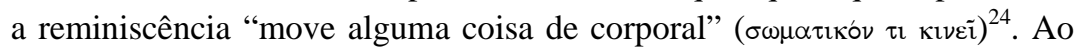
lermos estas linhas, poderíamos ser tentados a objetar que a reminiscência, se é uma pesquisa em algo corporal, não é necessariamente ela mesma corporal. Na realidade, como veremos mais adiante, as operações mentais que definem os atos de reminiscência são movimentos no sentido físico do termo, e não operações puramente mentais, que se poderia abstrair de seu

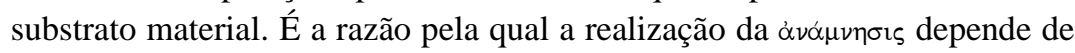
um certo número de condições fisiológicas, e é isto que explica suas freqüentes disfunções, assim como as da memória em geral. Não é, por conseguinte, por acaso que Aristóteles, na passagem citada, dá um valor irretorquível aos problemas da rememoração. No que segue imediatamente, ele evoca na mesma ordem de idéias: os casos melancólicos, cuja agitação ao mesmo tempo mental e de humor afeta a capacidade de rememoração; os indivíduos que têm muita umidade em torna da região sensitiva - a saber, o coração -, e que são assim os mais perturbados; os indivíduos de pequena altura, que tem uma má memória porque suportam maior peso sobre a parte sensitiva; as crianças e os idosos, nos quais os movimentos internos de crescimento e declínio incomodam os da memória ${ }^{25}$. Aristóteles evoca, além disto, este tipo de fatores de variações a propósito da memória em geral e

\footnotetext{
${ }^{23}$ De Mem., 2, 453 a 14-17.

${ }^{24}$ De Mem., 2, 453 a 22.

${ }_{25}$ De Mem., 2, 453 a 18-b 7.
} 
não somente da reminiscência ${ }^{26}$. A aptidão à memória ou à reminiscência varia, então, de uma espécie à outra, e de um indivíduo a outro ${ }^{27}$, porque ela depende intimamente do equilíbrio dos movimentos internos que aproximam o órgão principal da sensibilidade. Compreendemos melhor por estes exemplos porque a memória é uma aptidão comum à ala e ao corpo, sem que devêssemos entender por isto uma distinção real entre os dois termos desta comunidade. De uma parte, a memória depende de condições fisiológicas, de modo que seu estudo, como o conjunto das questões tratadas nos Parva naturalia, exige que conheçamos as propriedades físicas que regem estas condições. De outra parte, ela é um ato que alma executa ao mesmo tempo sobre o corpo e por seu intermediário.

Assim, afirmar que a memória é um estado "comum à alma e ao corpo" reenvia à idéia de uma atividade comum, na qual a alma desempenha o papel do motor e do agente, e o corpo o papel do movido e do paciente. O De anima está, sem equívoco, sob o registro geral desta "comunidade", definindo precisamente a unidade da alma e do corpo em termos de uma relação entre um agente e um paciente: "Devido à

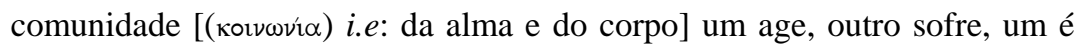
movido, o outro move, mas nenhuma destas propriedades recíprocas pertencem à coisas tomadas ao acaso" ${ }^{28}$. Aristóteles critica aqui aos que trataram da alma antes dele, e em particular Platão, de tê-lo feito sem considerar realmente as propriedades que, nesta relação, são aquelas do corpo. Assim, os pitagóricos parecem admitir que não importa qual alma pode vir em não importa qual corpo, como se a arte do carpinteiro viesse nas flautas. É a arte do músico, e não do carpinteiro, que faz propriamente da flauta seu "instrumento", da mesma maneira que o corpo deve dispor de propriedades funcionais determinadas, que fazem que ele seja o instrumento desta alma e não de outra ${ }^{29}$. Isto implica, ao contrário, que as propriedades que lhe faltam, enquanto corpo, para ser princípio de vida ou alma, são elas também determinadas: nenhuma ação e nenhuma paixão podem se realizar entre os termos sem relações, ou entre os termos absolutamente idênticos ou

\footnotetext{
${ }^{26}$ De Mem., 1, 450 a 30-b 11.

${ }_{27}$ PH. VAN DER EIJK, art. cit., sublinha a importância destas "variações" fisiológicas para a explicação das diferenças qualitativas no exercício das capacidades intelectuais.

${ }^{28} \mathrm{De}$ An., I, 3, 407 b 17-19.

${ }^{29}$ De An., l, 3, 407 b 20-26.
} 
semelhantes, porque a ação se exerce entre termos $\operatorname{contrários}^{30}$. A comunidade da alma e do corpo é, então, feita ao mesmo tempo de homogeneidade e de contrariedade: o corpo é, enquanto causa material, privado das determinações que a alma lhe aporta pelo jogo da tripla causalidade formal, eficiente, e final. Inversamente, porque as propriedades "agente” e "paciente” são relativas uma a outra, a maneira pela qual o corpo está disposto condiciona e influencia a maneira pela qual a alma exerce sobre ele sua função de agente: da mesma forma que o fato de ser inflamável é uma condição necessária da ação do que o inflama, o corpo é, por assim dizer, "animável” e, como tal, condiciona as atividades que a alma exerce sobre ele e por seu intermédio. O composto é, por conseguinte, por ele mesmo, motor e movido, agente e paciente, mutável e mudado ${ }^{31}$. O De memoria, ao explicar a memória segundo um modelo dinâmico, dá uma imagem bastante precisa desta relação.

\section{Memória e movimento}

A gênese da lembrança obedece a princípios muito simples. Os textos são, além disto, claramente convergentes sobre este ponto, tanto no interior quanto no exterior do corpus biológico. O início da Metafísica nos ensina que, nos animais que a possuem, a memória provém da sensação e

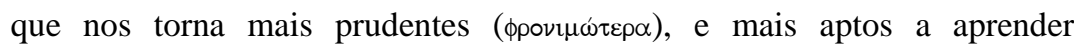
( $\mu \alpha \theta \eta \tau \iota \kappa \omega ́ \tau \varepsilon p \alpha)$ que os outros. Contudo, os outros animais que não o homem têm principalmente imagens ( $\phi \alpha \nu \tau \alpha \sigma^{\prime} \alpha$ l) e lembranças ( $\mu \nu \eta \mu \alpha$ l), e eles pouco participam no que concerne à experiência ( $\left.\dot{\varepsilon} \mu \pi \varepsilon \varphi^{\prime} \alpha\right)$. Não deixa de ser verdade que esta não tem outra origem do que a memória ela mesma. Independente das dificuldades colocadas por esta distribuição aproximativa das faculdades segundo uma scala naturae mal definida, este texto mostra que a memória constitui um primeiro nível de síntese cognitiva, e que a repetição da lembrança conduz a uma outra síntese que, no homem, faz experiência: "nos homens, a experiência vem da memória, pois várias lembranças da mesma coisa acabam por produzir potencialmente uma única

\footnotetext{
${ }^{30}$ Gen. Corr., I, 7, 323 b 17-324 a 19.

31 Ver neste sentido WATERLOW, S.. Nature, change and agency in Aristotle's Physics. Oxford: Clarendon Press, 1982, p. 213-216.
} 
experiência”32. A multiplicidade das lembranças produz assim uma certa aptidão para a experiência, sem ser ainda, propriamente falando, uma

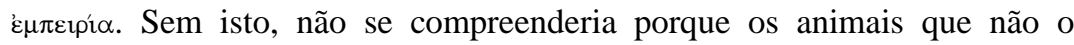
homem, que seguramente podem ter várias lembranças de uma mesma coisa, não beneficiariam da mesma aptidão. Enquanto tal, a multiplicidade de lembranças de uma mesma coisa constitui, então, potencialmente, uma experiência e, no homem, ela é uma experiência efetiva. Notamos igualmente que as lembranças estão associadas às imagens de uma maneira ainda imprecisa, mas que o De Memoria nos permitirá melhor caracterizar.

Os Segundos analíticos, que concluem por uma revisão das faculdades do conhecimento a fim de resolver o problema do fundamento da ciência, vão no mesmo sentido, apontando, contudo, precisões suplementares:

todos os animais (...) possuem uma capacidade de discernimento que lhes é conatural, e que chamamos

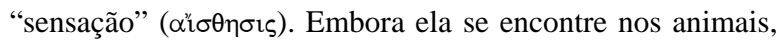
uma retenção da impressão sensível ( $\alpha$ ‘ $\sigma \theta \eta \mu \alpha)$ se forma em alguns deles, mas não em outros. Para todos aqueles que, por conseguinte, em que ela não se forma, não há conhecimento fora do ato de sentir, assim como, em geral, para o que não deixa impressão. Quanto àqueles nos quais ela se encontra, uma vez que sentiram, eles a possuem ainda na sua alma. Quando isto se produziu várias vezes, há uma diferença entre aqueles em que se forma uma noção ( $\lambda$ ó $\circ$ ), a partir da retenção destas impressões e aqueles em que isto não é o caso. Assim, da sensação vem a memória, como dissemos, e da memória, quando esta se aplica frequentemente ao mesmo objeto, vem a experiência $(\varepsilon \mu \pi \varepsilon i p i \alpha)$, pois uma multiplicidade numérica de lembranças constitui uma experiência uma ${ }^{33}$.

Esta passagem confirma globalmente a gradação esboçada na Metafísica. Sobre o plano epistemológico, ela estabelece que a memória constitui um testemunho fiável da aptidão da sensação para descriminar

\footnotetext{
32 Met., A 1, 980 b 29-981 a 1. A passagem que resumo começa em 980 a 27.
}

${ }^{33} \mathrm{Sec}$. an., II, 19, 99 b $34-100^{\mathrm{a}} 6$. 
entre as propriedades dos objetos sensíveis - o calor e o frio, o doce e o amargo etc. - e para preparar a apreensão - propriamente racional - dos conceitos os noções. Sobre um plano mais estritamente psicológico, ela evoca o processo geral de derivação de imagens a partir da sensação, que pode ser resumido da seguinte maneira: a afecção que produz a sensação em ato, transmite o movimento que o anima por contigüidade, e isto mesmo na ausência do motor que constitui o objeto sensível ${ }^{34}$. É porque a impressão sensível $\left(\alpha \alpha^{\prime} \sigma \theta \eta \mu \alpha\right)$ deixada pela sensação em ato reside não somente nos órgão sensoriais periféricos, mas também no coração, o órgão sensorial

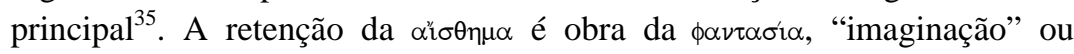

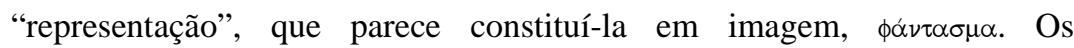
movimentos consecutivos à sensação em ato são, então, "movimentos imaginativos $(\phi \alpha v \tau \alpha \sigma \tau \iota \kappa \alpha i))^{36}$. Esta explicação da formação das imagens parece, à primeira vista, identificar imagem e lembrança, na medida em que toda imagem é a retenção de umtraço de um evento psíquico anterior e onde toda lembrança tem a textura de uma imagem. De fato, a lembrança está, em face da sensação, na mesma relação de proveniência que toda imagem: a memória não é a sensação, que concerne por sua parte a algo de presente, e toda imagem é precisamente uma forma de representação na ausência. Da

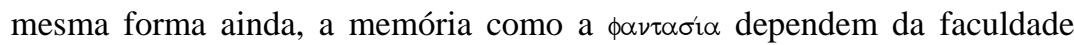
sensível primeira, que Aristóteles, no De memoria, parece assimilar à faculdade sensível comum ${ }^{37}$. Memória e imaginação são, assim, distintas da percepção dos sensíveis próprios (visão do visível, audição do audível etc.), mas pertencem à faculdade sensível comum: a percepção das propriedades

\footnotetext{
${ }^{34}$ Ver De Ins. (Dos sonhos), 2, 459 a 23-b 7. Sobre a aplicação à psicologia do princípio da transmissão do movimento na ausência do motor, ver De Mem., 2, 453 a 14-31; De Somno (Do sonho e da vigília), 3, 457 a 27; De Ins., 3, 461 a 22; De Div. (Da adivinhação no sono), 2, 463 b 17, 464 a 32 e Problemata (Problemas), XXX, 1.

${ }^{35}$ De Ins., 2, 459 b 5-7.

${ }^{36}$ De Ins., 3, 462 a 8-9. Sobre este processo, ver também De An., III, 2, 425 b 20-25; III, 3, 428 b 10-429 a 2 .

37 Ver neste sentido R. Sorabji, op. cit., p. 76; R. King, Aristoteles, De Memoria et reminiscentia, em Grumach, E.; FLASHAR, H. Aristoteles Werke in Deutscher Übersetzung, Band 14, Teil II. Berlin: Akademia Verlag, 2004, p. 32 (esta obra contém uma abundante bibliografia sobre o De Memória, a mais recente atualmente). Infelizmente, o texto do De Mem., I, 450 a 10-14 não é perfeitamente claro. Para uma análise precisa desta passagem, ver TAORMINA, D. "Perception Du temps et mémoire chez Aristote" (De Memoria et reminiscentia, 1). Philosophie Antique, II, 2002, p. 47-49, que propõe, por sua parte, distinguir "sensibilidade primeira" e "sensibilidade comum".
} 
sensíveis comuns aos diferentes sensíveis próprios, ou sensíveis comuns ${ }^{38}$ como a figura, a grandeza ou o movimento -; a percepção interna pelo fato de sentirmos ${ }^{39}$; a atribuição de diferentes propriedades sensíveis a uma mesmo objeto ou síntese perceptiva ${ }^{40}$.

Na realidade, toda imagem não é exatamente uma lembrança, não mais que esta não é redutível à posse de uma imagem. De outra parte, a imagem onírica, por exemplo, não é uma lembrança, pois ela nos deixa crer que o objeto representado está efetivamente presente, enquanto que a memória identifica sempre seu objeto como passado: é porque “os animais que percebem o tempo são os únicos a se lembrar”“41. É necessário entender por esta afirmação, não somente que a lembrança supõe a aptidão para perceber o tempo, mas também que uma certa percepção do tempo acompanha necessariamente, atualmente, todo ato de memória:

cada vez, com efeito, como foi dito precedentemente, que rememoramos, porque já vimos, ouvimos ou aprendemos tal coisa, percebemos, além disto, que isto se produziu anteriormente. Ora, o anterior e o posterior estão no tempo ${ }^{42}$.

De outra parte, e deste fato mesmo, a lembrança não é redutível à imagem enquanto tal: ela é antes um certo uso da imagem, ou uma maneira de dar sentido à uma imagem, relacionando-a à outra coisa que ela mesma, e a um evento passado. Ao me lembrar da noite de ontem, não me contento de visualizar a imagem interiormente: eu me represento esta imagem como a imagem de um evento passado. Nós retornaremos sobre este ponto essencial ao examinarmos os objetos da memória. É necessário reter, no momento, que a memória depende de nossa aptidão para figurar ou para imaginar, mas que se distingue disto em lhes especificando. É claro, em todo caso, que tanto a memória como a imaginação são estados ou movimentos da faculdade sensível ampliada às situações em que o objeto da

\footnotetext{
38 Ver especialmente De An., III, 2, 425 a 14-b 11.

${ }^{39}$ De An., III, 2, 425 b 12-25.

40 De $A n .$, III, 2, 426 b 8-427 a 14.

41 De Mem., 1, 449 b 28-29.

${ }^{42}$ De Mem., 1, 450 a 19-22.
} 
sensação não está mais atualmente dado ${ }^{43}$. Assim, embora a memória esteja ligada ao exercício da faculdade racional, ela não lhe pertence propriamente, o que explica que um bom número de animais, que não o homem, tenham lembranças e imagens. O mecanismo da memória, e o dinamismo que ele induz são, em todo caso, igualmente, os da imaginação.

A reminiscência, como vimos ${ }^{44}$, é propriamente humana. É difícil

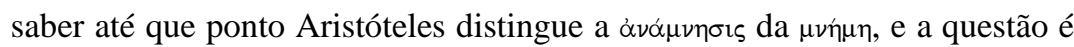
disputada $^{45}$. O De memoria divide-se em dois capítulos, consagrados respectivamente à memória e à reminiscência, e Aristóteles assinala, desde as primeiras linhas, que os indivíduos que fazem bom uso da $\alpha v \alpha \dot{\alpha} \mu \nu \eta \sigma ı$ não são os que têm boa memória ${ }^{46}$. Nós veremos mais adiante, entretanto, ao analisar os objetos e os usos da memória, que estas indicações não devem nos conduzir a isolar a reminiscência da memória entendida como aptidão geral à representação de alguma coisa do passado. Notamos até o presente que o processo pelo qual nós exercemos a reminiscência não é de todo diferente daquele pelo qual nós adquirimos a lembrança dos eventos, na medida em que ele se explica, ele também, pela teoria dos processos mecânicos espontâneos. Aplicada ao caso da reminiscência, esta teoria se caracteriza por quatro aspectos. Primeiramente, nós vimos, a reminiscência

\footnotetext{
${ }^{43}$ A questão de saber se a imaginação constitui uma faculdade de pleno direito, ou se é somente um aspecto da faculdade sensível, é disputado, e não posso aqui desenvolvê-la (eu reenvio para mais precisões para P.-M. Morel, op. cit., p. 34-49). Na perspectiva dos Parva naturalia, em todo caso, mais conformemente à definição da imaginação dana no De Anima - um movimento engendrado dob o efeito

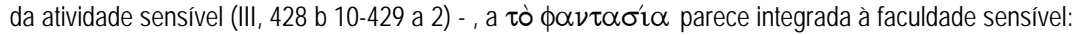
"já que falamos da imaginação no tratado $D a$ alma, e que a faculdade imaginativa ( $\tau \grave{\text { ò }} \phi \alpha \nu \tau \alpha \sigma \tau \iota \kappa o ̀ \nu)$ e a faculdade sensível ( $\tau$ ò $\left.\alpha^{\prime} \iota \theta \eta \tau \imath \kappa o ́ v\right)$ são a mesma coisa, embora na sua essência a faculdade imaginativa e a faculdade sensível difiram uma da outra; já que a imaginação é o movimento engendrado sob o efeito da sensação em ato e que o sonho parece ser um tipo de imagem (...), é manifesto que o fato de sonhar depende da faculdade sensível, mas enquanto ela é imaginativa" (De Ins., 1, 459 a 14-22).

${ }^{44}$ Conforme o De Memoria, mas também segundo a História dos animais, l, 488 b 24-26.

${ }^{45}$ R. Sorabji, op. cit., p. 41, insiste sobretudo sobre as diferenças entre memória e reminiscência (recollection). J. Annas, art. cit., as concebe como dois tipos De Memórias, a reminiscência sendo antes, segundo ela, uma memória "não pessoal" (ver mais abaixo, n. 48). C. Veloso, "Aristóteles. Da lembrança e da rememoração. De Memoria et reminiscentia", Cadernos de História e Filosofia da Ciência, 3, XII, 2002, número especial, p. 12-13, contesta que elas possam pertencer a um gênero comum, e estima que a memória depende da capacidade perceptiva e a reminiscência da faculdade intelectiva, mesmo se elas não estão completamente separadas. R. King, art. cit., p. 54-55, detalhando as diferenças e os pontos comuns entre memória e reminiscência, nota em particular que a reminiscência pode conduzir a uma lembrança, e conclui que ela emana da memória considerada em geral.

${ }^{46}$ De Mem., 1, 449 b 7-9.
} 
pressupõe um saber anteriormente adquirido, que se trate de um conhecimento científico, de uma sensação, ou de uma lembrança. Nisto, ela depende da memória entendida em sentido amplo, como a capacidade de tornar uma representação interiormente presente, referindo-se a um estado passado. É porque, como a memória, a reminiscência não se produz antes que um certo tempo tenha passado. Ela se caracteriza, é verdade, pelo fato que ela consiste e em "readquirir" 47 um saber anterior, que pode ser uma lembrança, mas também uma sensação ou um conhecimento que ainda não deram lugar a uma lembrança propriamente dita. Contudo, alguma coisa deste primeiro saber foi bem conservado, sem o quê não reconheceríamos como tendo sido experimentado anteriormente ${ }^{48}$. Aristóteles indica a este propósito que aprender e descobrir duas vezes a mesma coisa não é exatamente ter reminiscência dela ${ }^{49}$. Isto não é simples repetição da afecção ou do saber anteriormente experimentado, mas a "retomada" ( $\dot{\alpha} v \dot{\alpha} \lambda \eta \psi 1 \varsigma)$, isto é, o reconhecimento de um objeto que havia cessado de ser tomado como objeto. Deste ponto de vista, a $\alpha v \alpha \dot{\mu} \mu \nu \eta \sigma ı s$ aristotélica corresponde estritamente à idéia contemporânea da reminiscência como reconhecimento do que nos era familiar, que havia cessado de sê-lo, mas que reaparece de modo idêntico à sua primeira manifestação.

A explicação deste fenômeno supõe o recurso à teoria fisioçógica dos traço sensíveis, que permitem a formação das imagens em geral, e da qual vimos a importância no caso da memória simples. Contudo, no caso da reminiscência, Aristóteles insiste particularmente sobre o aspecto dinâmico do processo, e é isto a sua segunda característica: "as reminiscências

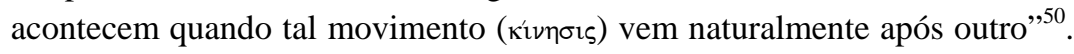

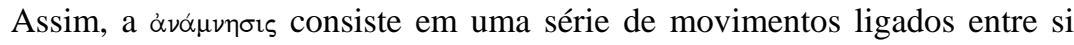
por um tipo de efeito de inércia, um estado mental levando ao seguinte por

\footnotetext{
${ }^{47}$ De Mem., 2, 452 b 2.
}

${ }^{48} \mathrm{~J}$. Annas, art. cit., estima que a reminiscência é um tipo de memória "não pessoal", porque ela não implica que lembremos de ter aprendido o que se rememora. Contudo, ao nos lembrarmos de algo - a lista dos imperadores romanos, as partículas inseparáveis dos verbos alemães etc. - podemos não nos lembrar das circunstâncias ou do momento da aprendizagem, mesmo tendo consciência de ter aprendido, num passado indeterminado, e em circunstâncias que nos escapam presentemente. Em conseqüência, a distinção entre uma memória "pessoal" - no sentido de Annas: nos recordamos de ter aprendido $x$ - e memória "não pessoal", torna-se muito confusa, e finalmente pouca esclarecedora para a problemática aristotélica.

${ }^{49}$ De Mem., 2, 451 b 6-10.

${ }^{50}$ De Mem., 2, 452 b 10-11. 
uma dinâmica própria à série que eles constituem ou da qual fazem parte. Este dinamismo não deve ser mal compreendido: Aristóteles, nós sabemos, não entende necessariamente por "movimento" um movimento local, e ele pode subentender que cada estado mental é um movimento no sentido em

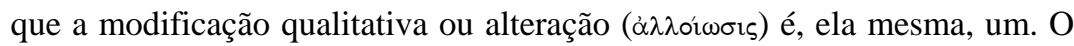
ponto essencial é este: todo movimento produz necessariamente um efeito cinético sobre os corpos ou estados corporais que lhes são contíguos. Ora, já que cada estado mental é igualmente um estado corporal, os estados mentais produzem efeitos cinéticos os que lhes são contíguos. Cada estado mental provoca seu "sucessor imediato" ( imediatamente contíguo ${ }^{51}$.

Em terceiro lugar, estas séries cinéticas produzem traços persistentes no sistema ou na rede das imagens que constituem a paisagem mental: elas produzem hábitos, isto é, disposições adquiridas e estáveis que permitem a repetição delas, mesmo se esta não pudesse ter a regularidade absoluta dos encadeamentos estritamente necessários. Por conseqüência, a reminiscência nos oferece a possibilidade de organizar nossas próprias representações em séries mecânicas no termo das quais nós estaremos praticamente assegurados de reapreender um saber provisoriamente esquecido, ou simplesmente não objetivado:

Quando, por conseguinte, experimentamos a reminiscência, nós experimentamos alguns movimentos anteriores, justo a que tenhamos experimentado o movimento após o qual o movimento em questão adquiriu o hábito de se produzir. É por esta razão, que nós perseguimos o sucessor imediato, procedendo mentalmente a partir do momento presente, ou de algum outro momento, e a partir do semelhante, do contrário ou do vizinho. Eis o que produz a reminiscência ${ }^{52}$.

Aristóteles permanece muito evasivo sobre a natureza física exata dos estados mentais concernidos e sobre os fatores fisiológicos que permitem a formação dos hábitos mentais. Parece, todavia, que seu

\footnotetext{
51 Ver 0 texto citado abaixo. Trata-se de uma aplicação da definição do sucessor dado na Física, V, 3 , 226 b $34-227$ a 1.

52 De Mem., 2, 451 b 16-20.
} 
propósito não seja o de produzir uma explicação positiva do processo, mas antes de mostrar os princípios destes e o mecanismo geral. Ele evoca, mais tarde, diferentes tipos de exercícios de rememoração segundo um sistema de justaposição de lugares ${ }^{53}$ : cada lugar ( imediatamente a seu sucessor por um tipo de associação de idéias. Esta concepção do uso da reminiscência é muito mais próxima da técnica mnemônica do sofista Hippias do que da anamnese platônica ${ }^{54}$. Aristóteles dá um exemplo relativamente anódino, mas que exprime bem tudo o que promete, no domínio do exercício intelectual e da aquisição do saber, o controle do processo de reminiscência:

Parece às vezes que a reminiscência se exerce a partir de lugares comuns. A causa disto é que passamos rapidamente de uma coisa à outra, como do leite ao branco, do branco ao ar, deste ao úmido, a partir do qual nos lembramos do outono, se é a estação que procuramos ${ }^{55}$.

Podemos supor que para encontrar o nome ou a ordem das estações, associaremos o leite ao outono, suscitando, a partir da representação do leite, a série: leite/branco/ar/umidade/outono. Tudo leva a pensar que este tipo de procedimento se aplica igualmente a outros domínios de competência, como mostram os diagramas descritos no capítulo 2 do $D e$ memoria, e que figuram o percurso mental das séries mnemônicas, religando os termos indeterminados (A, B, C, D,...). Aristóteles justifica este método invocando o raciocínio matemático:

Do mesmo modo que as coisas se sucedem imediatamente umas às outras, o mesmo se dá com os movimentos. Também é fácil de lembrar as coisas que apresentam uma certa ordem, como os objetos matemáticos, enquanto que em

\footnotetext{
${ }_{53}$ De Mem.,2, 452 a 13. Sobre os sistemas dos lugares, ver em particular o desenvolvimento elaborado por R. Sorabji, op. cit., p. 22-34.

${ }^{54}$ Para Hippias, ver Platão, Hippias maior, 285 e; Hippias Menor, 368 d.

${ }_{55}$ De Mem., 2, 452 a 12-16.
} 
relação às outras coisas, lembramo-nos mal e com dificuldade $^{56}$.

O hábito rememorativo atinge, em todo caso, uma regularidade igual àquela dos fenômenos naturais, e é neste sentido que o hábito é uma segunda natureza, ou mais precisamente, acaba por ser como uma natureza" ${ }^{57}$. Ela torna-se, assim, o motor de uma atitude de pesquisa e de raciocínio $^{58}$. É um ponto sobre o qual nós teremos de retornar, pois ele explica a importância da memória e da reminiscência para toda pesquisa teórica.

Enfim, quarta característica do processo de reminiscência, ele tem por primeiro princípio e ponto de partida um princípio interno, isto é, um princípio que está à disposição do agente. Para realizar uma pesquisa e chegar a seu termo, segundo um processo que controlamos, é necessário, com efeito, que "nos movamos a partir de nós mesmos e dos movimentos que possuímos" 59 . Do mesmo modo que ao lembrarmos de alguns versos de um poema, nos lembramos mais facilmente de outros, nós devemos partir do que já possuímos, para percorrer toda a série de elementos conexos, que isto seja em direção dos termos anteriores ou em direção dos termos posteriores. Ainda assim, é necessário ter em consideração os fatores fisiológicos no decorrer do processo: se o agente não está disposto fisicamente a fazer um bom uso da reminiscência - que ele seja muito agitado, demasiado seco ou demasiado úmido, demasiado jovem ou velho, ou ainda desproporcionado morfologicamente -, ele não chegará a escolher o ponto de partida da série e a controlar a sucessão dos termos que a compõe $^{60}$. As múltiplas disfunções da memória e do encadeamento das representações confirmam, então, que a reminiscência consiste, como a memória em geral, em procurar uma imagem em um elemento corporal ${ }^{61}$.

\footnotetext{
${ }^{56}$ De Mem., 2, 452 a 1-4.

57 De Mem., 2, 452 a 27-28. Sobre este ponto, envio a MOREL, P.-M. "L'habitude, une second nature?".In: MOREL, P.-M. (ed.). Aristote et la notion de nature. Enjeux épistémologiques et pratiques. Bordeaux: PUB, 1997, p. 131-148.

${ }^{58}$ De Mem., 2, 453 a 12-14.

${ }^{59}$ De Mem., 2, 452 a 11-12.

60 De Mem., 2, 453 a 14-b 7.

${ }^{61}$ De Mem., 2, 453 a 14-16.
} 


\section{Objetos e usos da memória}

A explicação da gênese da memória, e da reminiscência, em particular, permite pensar, ao menos em uma primeira abordagem, que Aristóteles tende a materializar ou a naturalizar integralmente os eventos mentais. A situação é, em realidade, mais complexa, assim como o mostra a análise dos objetos e dos usos da memória e da reminiscência.

Comecemos pela formação da lembrança imediata, isto é, da lembrança na qual a atualização não resulta de um processo de reminiscência. Como vimos, a $\mu \nu \eta \mu \eta$, à diferença da sensação e da antecipação do devir, trata de algo de ausente e do passado:

não é possível se lembrar do futuro, que é objeto de conjectura e de previsão (existiria mesmo uma ciência da previsão, como alguns o dizem falando da adivinhação), assim como não há também lembrança do presente, mas é isto o objeto da sensação. Por meio desta, com efeito, não conhecemos nem o futuro, nem o passado, mas somente o presente. A memória concerne ao passado ${ }^{62}$.

Nas linhas que seguem, Aristóteles opõe, pela mesma razão, a lembrança ao saber em ato: se exercemos a ciência, se compreendemos em ato os objetos da ciência, então nós não nos satisfazemos de nos lembrarmos deles, pois eles nos são efetivamente presentes. No momento em que eu efetuo as operações com o triângulo, o objeto inteligível "triângulo" me é efetivamente presente, mesmo se eu tivesse de me lembrar, antes ou por algum motivo, de um certo número de propriedades geométricas. Em todo estado de causa, no momento em que eu penso efetivamente o triangulo, eu não posso dizer que eu tenho unicamente a lembrança dele.

Poder-se-ia objetar a Aristóteles que um tipo de memória fundamental se mistura sempre à consciência do presente, ou ainda que a representação do passado se introduza sempre sob a consideração do presente, mas faltaria então a originalidade de sua proposta: identificar um critério da lembrança enquanto tal. Isto não quer dizer que a lembrança é totalmente hermética ao presente e à antecipação do futuro. O que faz com

${ }^{62}$ De Mem., l, 449 b 10-15. 
que a lembrança não se confunda com nenhum outro tipo de representação, é que ela trata do passado: quando lembramos, "se diz na sua alma o que se entendeu, ou sentiu, ou pensou isto anteriormente" ${ }^{63}$. Aristóteles pode invocar, sobre esse ponto, a opinião comum que discerne espontaneamente a especificidade objetiva da memória:

Ninguém diria se lembrar do presente no momento em que ele é presente, como desta coisa branca no momento em que a olha, mas não se diria se lembrar do objeto estudado no momento em que se o está a estudar e a pensar; mas se diz somente, no primeiro caso, que se sente e, no segundo caso, que se sabe. ${ }^{64}$

A memória é, com efeito, uma faculdade de formação, de conservação, mas também de rememoração de imagens. Por consequencia, ela não se reduz a só uma presença de uma imagem como traço físico. De um lado, a memória é ao mesmo tempo a percepção de um traço sensível de um objeto ou de um evento particular e uma percepção do tempo. De outro lado, ela apreende a imagem como imagem, o que significa que ela a distingue espontaneamente daquilo do qual ela é a imagem, o que não é o caso, por exemplo, de uma imagem onírica.

Comecemos pela percepção do tempo. Ela é explicitamente evocada no De memoria. Aristóteles indica que só os animais que "percebem" ( $\alpha$ ı $\theta \dot{\alpha} v \varepsilon \tau \alpha$ ) o tempo têm lembranças, porque "toda lembrança está ligada ao

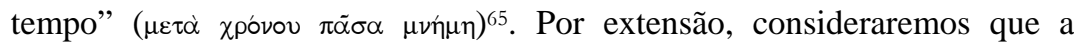
memória implica a apreensão dos sensíveis comuns, como a grandeza ou o movimento, aos quais o tempo está aqui associado. ${ }^{66}$ Isso confirma, se é necessário, que a memória não está contida na sensação própria, e convida a pensar que ela depende da faculdade sensível comum. O exercício da reminiscência exige, além disso, uma certa medida do tempo, ou ao menos, uma apreciação aproximativa do tempo esgotado a fim de reapreender o

\footnotetext{
${ }^{63}$ De Mem., l, 449 b 22-23.

${ }^{64}$ De Mem., I, 449 b 15-18.

${ }^{65}$ De Mem., I, 449 b 28-29.

${ }^{66}$ De Mem., I 450 a 8. D. TAORMINA, art. cit., p. 46, nota que o tempo não é habitualmente citado por Aristóteles na lista dos sensíveis comuns. Podemos assim também considerar que a apreensão do tempo deriva, por acidente, daquela do movimento. Ver infra.
} 
objeto procurado ${ }^{67}$. Este ponto se explica facilmente se consideramos que a memória supõe a apreensão de uma relação de anterioridade/posteridade, pois "o anterior e o posterior estão no tempo" 68 , conforme os ensinamentos do livro IV da Física e à definição do tempo como medida do movimento segundo o antes e o depois. Podemos, além disso, supor que não se trata somente da medida dos movimentos externos, isto é, da percepção cronológica dos eventos mundanos: a relação de anterioridade/posteridade concerne igualmente aos estados mentais e à cronologia interior da história pessoal. Dizer “em sua alma” que algo se produziu anteriormente é também discernir uma ordem de sucessão entre as próprias afecções ou estados mentais. O que não ocorre no caso dos dormidores da Sardenha evocados na Física, que repousam em um local consagrado e que não têm consciência, quando se lhes acorda, que o tempo passou ${ }^{69}$. Assim, a "percepção" do tempo é ainda mais imediata que há, para Aristóteles, um tipo de consciência íntima do tempo.

Podemos, entretanto, passar, sem intermediação, da temporalidade da lembrança - o fato de que a memória é acompanhada do tempo, a uma "percepção" efetiva do tempo? Se observamos as coisas de mais perto, o texto De memoria indica que os animais que percebem o tempo são os únicos a se lembrar, mais isso não quer dizer exatamente que a memória seja uma percepção direta do tempo. A definição da memória é, sobre esse ponto, muito elíptica: “a memória não é, por conseguinte, nem crença, mas uma disposição ou uma afecção se relacionando a uma delas, quando o tempo passou”70 (eu sublinho a proposição concernida). A memória supõe então o tempo como uma condição necessária, ou como o modo de ligação entre o estado de lembrança e isto a que ele se refere. Isso não quer dizer que a consciência do conhecimento anterior seja desdobrada, no interior da própria memória, por um tipo de lembrança do tempo. É necessário, de resto, que o tempo esteja ainda presente e constitua um único continuum para que nós possamos dizer que um evento passou, em relação a um presente que se situa em uma temporalidade comum com este evento. Ora, a memória, longe de ser uma percepção do tempo como tal, sob seus três

\footnotetext{
${ }^{67}$ De Mem., 2, 452 b 23-453 a 4.

68 De Mem., 1, 450 a 21-22.

${ }^{69}$ Phys., IV, 11, 218 b 21-27.

${ }^{70}$ De Mem., 1, 449 b 24-25.
} 
aspectos, é percepção do passado e não do presente e do futuro. A memória, assim entendida, não é a percepção efetiva do tempo ele mesmo, mas a percepção disto que está no tempo, enquanto pertence ao passado. Aristóteles acresce, mais adiante, que uma medida estrita do tempo não é necessária à lembrança, pois nós podemos nos lembrar de um evento sem reconhecer a exata quantidade de tempo decorrido ${ }^{71}$. Conforme a tese da Física IV, segundo a qual o tempo é "alguma coisa do movimento"72, ele não saberia ter disso mais do que uma percepção acidental ou ocasional do tempo. A memória é assim distinta em um sentido da percepção do tempo, embora ela lhe seja necessariamente correlacionada.

O essencial, entretanto, refere-se ao seguinte: associando imediatamente a memória e a percepção correlativa do tempo, Aristóteles assinala que a memória acrescenta algo a mais à imagem que sua simples presença material. Consideremos em efeito a compreensão da lembrança como imagem ${ }^{73}$. Podemos nos perguntar por que a lembrança estando presente, enquanto a coisa está ausente, a memória trata do que não está presente. Se, efetivamente, a memória é simplesmente a percepção interna de uma imagem conservada, ela não é uma percepção da coisa, mas dela mesma, por consequência não há propriamente memória ou lembrança da coisa. Se admitimos que, apesar de tudo, nos lembramos da coisa ausente, como explicar que nós tenhamos em nós a sensação de uma lembrança disto que, entretanto, nós não sentimos atualmente ${ }^{74}$ ? Em outros termos, a memória é um certo tipo de sensação interna e concerne então como toda sensação, a alguma coisa que está atualmente presente, e entretanto, ela permite ver alguma coisa que não está atualmente presente. A solução está na modalidade deste "permite ver", como o mostra bem a passagem seguinte:

Ocorre, com efeito, como para o animal desenhado sobre uma tabuleta. Ele é, ao mesmo tempo, um animal e uma

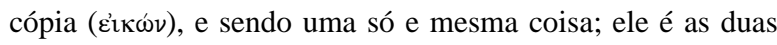
coisas ao mesmo tempo, embora estas não sejam idênticas, e

\footnotetext{
${ }^{71}$ De Mem., 2, 453 a 3-4.

72 Phys., IV, 11, 219 a 10.

${ }^{73}$ Ver a passagem De Mem., 1, 450 a 25-451 a 2.

${ }^{74}$ Esta aporia é exposta em De Mem.,1, 450 b 11-20.
} 
podemos observar tanto como animal quanto como cópia. Da mesma forma, também é necessário conceber a imagem ( $\phi \alpha ́ \nu \tau \alpha \sigma \mu \alpha)$ que está em nós ao mesmo tempo como alguma coisa por si e como a imagem de algo outro. Enquanto que ela é por si, ela é um objeto que se olha $(\theta \varepsilon \omega ́ p \eta \mu \alpha)$ ou uma imagem, mas enquanto que ela é uma imagem de algo outro, ela é um tipo de cópia e uma lembrança $(\mu \nu \eta \mu o ́ v \varepsilon v \mu \alpha)^{75}$.

$\mathrm{O}$ argumento consiste em distinguir entre a imagem enquanto estado mental, em sua consistência própria de traço fisiológico, e a imagem como imagem de ..., isto é, a imagem em sua dimensão intencional. Sob o segundo aspecto, a imagem adquire uma função representativa, como um quadro que distinguimos espontaneamente, em circunstâncias normais ${ }^{76}$, de seu referente objetivo. No caso da lembrança, a imagem é então sentida interiormente, mas ela é sentida como uma cópia ou um quadro porque seu objeto pertence ao passado, de modo que ela indica espontaneamente a ausência da coisa ausente. Graças a essa dupla natureza, e porque ela é acompanhada de uma percepção correlativa do tempo, a imagem mnemônica escapa então à aporia inicial ${ }^{77}$.

Poderíamos objetar que há ali uma petição de princípio, pois o texto deixa obscuros vários aspectos do processo em questão. É necessário atribuir à memória uma sensação redobrada, além da sensação interna da lembrança? É ela obra do senso comum? Aristóteles não deveria fornecer uma descrição fisiológica do fenômeno? Não podemos preencher as lacunas teóricas do texto De Memória, mas podemos reconstituir os princípios da explicação suplementar que faz falta aqui. É à imaginação que convém incontestavelmente atribuir a aptidão para figurar isto que não está presente, portanto, nessa circunstância, que ela está acompanhada do tempo. Ora as

\footnotetext{
${ }^{75}$ De Mem., 1, 450b 20-27.

${ }^{76}$ Aristóteles considera igualmente 0 caso em que se confunde a imagem com aquilo que ela representa (De Mem., 1, 451 a 2-14)

77 A "percepção" do tempo depende estreitamente da imaginação, como o mostra D. TAORMINA concluindo sua análise, art. cit., p. 59, "a percepção do tempo pressupõe as imagens, ela intervém sobre aquelas, e thes assinala a diferença. (...) a memória se serve da dimensão temporal para colocar ordem nos dados que ela conserva de forma estável e que, sem essa ordem, não seriam legíveis". Sobre essa passagem, ver igualmente LABARRIÈRE, J.-L. "Sentir le temps, regarder un tableau. Aristote et les images de la mémoire". In: DARBO-PESCHANSKI, C. (ed.). Constructions du temps dans Le monde grec ancien. Paris: CNRS Éditions, 2000, p. 269-283.
} 
imagens, embora elas se assemelhem às impressões sensíveis imediatas, e embora estejam originariamente ligadas a elas, têm de próprio que elas são "sem matéria"78. É necessário entender por essa fórmula, não que as imagens não tenham alguma dimensão corpórea, nem que as sensações são fenômenos puramente fisiológicos ${ }^{79}$, mas que a imagem não implica necessariamente a presença material de seu referente. No caso da memória, vimos, ela o exclui. A lembrança é, por conseguinte, a apreensão de uma forma ( $(\hat{i} \delta \circ \varsigma)$. Ora, nós podemos nos representar as formas, inclusive as formas dos inteligíveis, sem que seu substrato sensível esteja efetivamente presente, e isso mesmo se elas não existem em nenhum lugar a não ser nas realidades sensíveis. Mais ainda, é porque as determinações formais podem ser assim representadas que pode haver memória, isto é, sensação interna de uma imagem de qualquer coisa passada. De forma geral, a teoria aristotélica da memória se desmarca claramente de uma naturalização integral: a lembrança é uma imagem material do imaterial.

Compreendemos melhor, por esse viés, o papel que pode desempenhar a memória em geral no exercício da faculdade racional. Como nós vimos no texto dos Segundos Analíticos, a memória é um intermediário entre a sensação e a constituição da experiência, isto é, a primeira forma de apreensão do geral. Ela é então a primeira etapa, após a sensação, do processo indutivo e da apreensão natural das noções gerais. Contudo, o exercício efetivo e sábio do intelecto apela, ele também, à memória. Isso pode parecer depender do simples bom senso, mas Aristóteles insiste, mais geralmente, sobre a dependência da intelecção a respeito da $\phi \alpha v \tau \alpha \sigma i \alpha$. O De memória o lembra: não é possível pensar sem imagens ${ }^{80}$. Por sua aptidão a reter e a apresentar a imagem da forma, na ausência do objeto sensível, a imaginação aporta ao intelecto um suporte figurativo, por exemplo, para conceber as propriedades de uma figura geométrica. Aristóteles compara aqui a visualização mental do triângulo ao uso que o geômetra faz das figuras que ele traçou ${ }^{81}$. Essa operação espontânea se realiza no tempo, de

\footnotetext{
${ }^{78}$ De An., III, 8, 462 a 9-10.

${ }^{79}$ As sensações são percepções de formas "sem matéria", na medida em que elas não recebem nada da matéria do objeto percebido: elas apreendem somente a forma deste, como a cera do selo recebe a impressão sem conservar a matéria do carimbo (De An., II, 12, 424 a 17-21).

${ }^{80}$ De Mem., 1, 449 b, 30-31. O texto reenvia à De anima. Ver De An., III, 7, 431 a 16-17; 8, 432 a 8-9.

${ }^{81}$ De Mem., 1, 450 a 1-5.
} 
modo que "a memória pertence, por acidente, ao intelecto" embora ela pertença "por si à faculdade sensível primeira”"2.

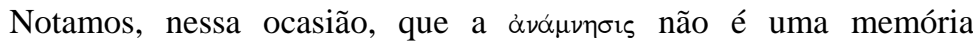
exclusivamente intelectual que se oporia a uma $\mu \nu \eta \mu \eta$ que não teria alguma relação com a intelecção, ou que a oposição desses dois termos só interrompe a da intelecção e da sensação. A reminiscência, é verdade, só pertence ao homem, porque sozinho, com todo o rigor, ele toma parte da faculdade racional: "a reminiscência é um tipo de raciocínio" ${ }^{83}$. Além disso, sendo uma busca deliberada, ela não saberia ser exercida por um ser que não possui a faculdade racional de deliberação ${ }^{84}$. Além do mais, ela se distingue também da memória porque ela consiste em se dar um objeto efetivamente presente. De uma parte, ela apreende a lembrança como um momento de uma série dada, e não como uma cópia do qual ele é a lembrança. De outra parte, ela reapreende um saber anteriormente adquirido e se atualiza em sua realidade efetiva: se eu não aprendi algo a mais sobre o triângulo desde ontem, não há diferença entre a minha concepção atual das propriedades do triângulo e a concepção, idêntica, que eu tinha ontem. O triângulo hoje não é, em todo caso, a lembrança do triângulo de ontem. ${ }^{85}$ Aristóteles não é muito preciso sobre as tarefas exatas que se pode esperar da reminiscência, e ele não diz a qual (quais) ciência(s) ou a qual tipo de competência é necessário relacioná-la. Podemos supor, em todo caso, que a reminiscência, quando ela depende de um método de treinamento, ela participa da aprendizagem ou do exercício, em vista de um controle mais fácil dos encadeamentos lógico, ou na perspectiva das discussões dialéticas. ${ }^{86}$

Entretanto, a reminiscência, porque ela se aplica às imagens e

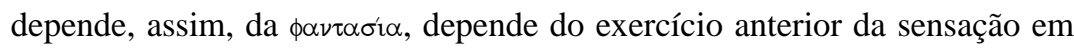

\footnotetext{
${ }^{82}$ De Mem., 1, 450 a 13-14.

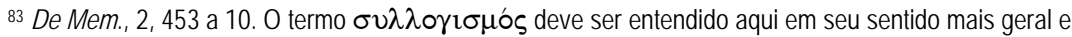
não necessariamente no sentido técnico de "silogismo", definido nos Analíticos.

${ }^{84}$ De Mem., 2, 453, a 10-14.

${ }^{85}$ Pode-se dizer, nesse sentido, seguindo-s sobre esse ponto a análise de J. Annas, que a reminiscência não revive - ou não necessariamente - a gênese da aprendizagem.

${ }^{86} \mathrm{Na}$ medida precisamente em que a dialética dos Tópicos tem como primeira utilidade servir ao treinamento intelectual (Top., I, 2, 101 a 28-30). Aristóteles convida, explicitamente, para uma boa prática da dialética, a guardar as premissas na memória segundo o método dos lugares (Top., VIII, 14, 163 b 22-32). Sobre essa questão, ver a argumentação esclarecedora de R. Sorabji, op. cit., p. 26-31.
} 
ato. Ela não pertence então a uma faculdade que seria totalmente separada do corpo: ela pertence à faculdade racional considerada na sua dimensão ao mesmo tempo psíquica e corporal. Ela não está, por conseguinte, em obra nas situações nas quais o intelecto pode ser denominado de "separado". O fato de que os textos de Aristóteles não sejam muito claros sobre esse ponto, e que tais situações sejam difíceis de identificar - trata-se da apreensão intuitiva dos inteligíveis simples de um intelecto superior, distinto do intelecto pessoal e corruptível? Ou ainda do ato de intelecção enquanto tal? - não se retire algo de essencial: a reminiscência depende originariamente da faculdade sensível e se exerce sobre as imagens; ela é uma atividade ao mesmo tempo intelectual e corporal.

A estreita relação que constatamos entre a reminiscência e a imaginação mostra a qual ponto é artificial separar a reminiscência da

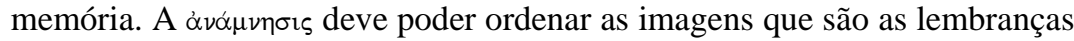
para suscitar voluntariamente a atualização de um saber anteriormente adquirido, percorrendo as séries assim definidas. A memória está desde o primeiro momento à disposição do intelecto e a reminiscência é, nesse caso, o uso operatório dessa colocação à disposição. Ao menos, supõe ela necessariamente o trabalho anterior da memória, pois mesmo no caso em que ela não consiste em recordar uma lembrança, ela se acompanha necessariamente da consciência da anterioridade da aquisição do saber. É a este respeito bastante revelador que Aristóteles fale frequentemente da reminiscência utilizando um léxico da memória ${ }^{87}$ e que nas últimas linhas ${ }^{88}$ do segundo capítulo do De Memória, capítulo em princípio consagrado à reminiscência, ele fala indistintamente das disfunções da memória e daquelas da reminiscência. Assim, mais do que isolar a reminiscência da memória, ou de opor “espécies” de memória, deveríamos nos distinguir dos aspectos funcionais da memória: o uso figurativo espontâneo da memória simples é ultrapassado, sem ser abolido, pelo uso operatório da reminiscência.

\footnotetext{
87 Ver, por exemplo, o levantamento dos termos da família de $\mu \nu \eta \dot{\eta} \mu \eta$ efetuado por J. Annas (art. cit., p. 298, n. 4). A título de exemplo, citamos a frase que segue imediatamente a definição da reminiscência:

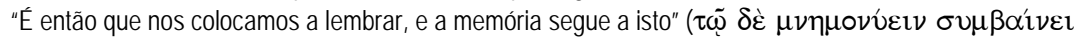

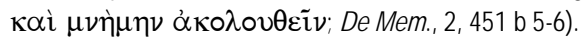

${ }^{88}$ De Mem., 2, 453 a 14-b 7.
} 
O caso da reminiscência sugere enfim uma solução à dificuldade inicialmente evocada: aquela da articulação, no trabalho da memória, da descontinuidade e da continuidade da experiência pessoal. Em primeiro lugar, nós vimos, a reminiscência efetiva, em oposição às sucessões de idéias involuntárias ou às rememorações errôneas, consiste a dar um ponto de partida em vista de uma busca e à decisão desta busca. Ela supõe então que se tenha, em si mesmo, uma faculdade motora ou uma potência produtora de movimentos ${ }^{89}$ que nos permite constituir deliberadamente as séries de movimentos, ou bem de percorrer, a um momento dado, uma série já constituída. Assim, a reminiscência, na medida em que supõe a presença interna de um princípio motor e em que ela é deliberada, é uma forma de ação mental, comparável à praxis no sentido estrito e antropológico do termo, isto é, à ação moralmente significativa. Ela é, nesse sentido, o fato de um agente capaz de exercer um controle eficaz sobre suas próprias representações. O método mnemotécnico descrito no segundo capítulo do De Memória indica, por conseguinte, que a memória, malgrado sua irredutível dimensão passiva, continua em nosso poder. Ao menos está em nosso poder ordenar de maneira global, e a propósito de objetos determinados, a maneira pela qual nos referimos às nossas próprias lembranças.

Em segundo lugar, na maior parte dos casos, a constituição dessas séries exige um exercício repetido, capaz de prevenir os fracassos da memória. Aristóteles o indica no final do primeiro capítulo do tratado, após de ter evocado os casos de confusão entre a lembrança e isto do qual ela é a cópia:

os exercícios ( $\mu \varepsilon \lambda \varepsilon \dot{\varepsilon} \tau \mathrm{l})$, contudo, preservam a memória pela repetição da lembrança, o que não é outra coisa que observála por várias vezes como uma cópia, e não como alguma coisa em $\mathrm{si}^{90}$.

O princípio que está em obra aqui é idêntico àquele que explica a aquisição das virtudes morais, como a coragem ou a generosidade ${ }^{91}$ : a

\footnotetext{
89 De Mem., 2, 452 a 10-11.

${ }^{90}$ De Mem., 1, 451 a 12-14.

${ }_{91}$ Ver Eth. Nic., II, 1.
} 


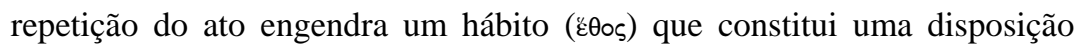
estável ( $(\xi \xi \varsigma)$ do caráter. Ora, essa disposição não é simples potencialidade indeterminada, uma potência que não teria qualquer efeito sobre nossas ações efetivas, de coragem ou de generosidade: porque ela é uma orientação

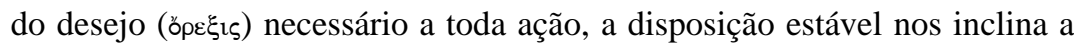
agir no sentido que ela define. Nosso texto é de toda evidência paralelo à refutação, na Ethica Nicomachea, III, 7, da fórmula socrática "ninguém é mau voluntariamente". Contra aqueles que objetam a Aristóteles que os intemperantes se tornaram incapazes de agir bem e, desse fato, não são mais responsáveis por suas más ações, Aristóteles responde que isso dependia desses últimos, inicialmente, de não cometer as ações que acabaram por produzir neles uma disposição à intemperança. Ele toma o exemplo daqueles que treinam para o combate, esportivo ou guerreiro, e ele faz uso, como no De Memoria, da noção de exercício: “é manifesto se consideramos o caso daqueles que se exercitam ( $\tau \tilde{\omega} v \mu \varepsilon \lambda \varepsilon \tau \omega \dot{\omega} \tau \omega \nu)$ em vista de um combate ou de qualquer outra ação, pois eles passam seu tempo a executar essas atividades”92. O mesmo princípio de aquisição do hábito por repetição de atos idênticos pode servir ao mal tanto quanto ao bem, mas é claro que, nos dois casos, nós somos responsáveis por isso, o que quer dizer que nós nos tornamos os primeiros agentes. De maneira ainda mais significativa, Aristóteles prossegue sua argumentação evocando a perpetuação dos movimentos sucessivos, para além do momento em que o motor produz o primeiro movimento, para explicar os vícios inveterados: "uma vez que alguém lançou uma pedra, ele não é mais capaz de retomá-la, porém dependia dele pegá-la e jogá-la, pois o princípio [isto é, desse ato] estava nele" ${ }^{33}$. Ora, no De Memoria, Aristóteles recorre à mesma metáfora para evocar o efeito de treinamento que produz a reminiscência e suas disfunções: “do mesmo modo que, quando lançamos algo, não está mais em nosso poder pará-lo, do mesmo modo também, aquele que rememora e persegue (uma imagem) coloca algo de corporal onde reside a afeç̧ão" ${ }^{\text {. }}$. De resto, acontece a Aristóteles, de qualificar a memória em geral de ع̌ $\xi ı \varsigma$ no

\footnotetext{
92 Eth. Nic., III, 7, 1114 a 7-9.

93 Eth. Nic., III, 1114 a 17-19. Seguindo o texto editado por NATALI, C. Aristotele, Etica Nicomachea. Roma-Bari: Laterza, 1999.

94 De Mem., 2, 453 a 20-23.
} 
sentido de "disposição" 95 . Assim, como nós somos, no domínio moral, globalmente responsáveis por nossas representações porque nós somos responsáveis por nossas disposições ${ }^{96}$, nós somos globalmente responsáveis pela ordem que nós instituímos entre nossas lembranças ou nossos conhecimentos. Nós podemos mesmo supor que nós somos parcialmente responsáveis, antes mesmo de toda reminiscência propriamente dita, da clareza ou da força das imagens elas mesmas: não cabe senão a nós preservar a memória pela repetição da lembrança e de considerá-la em várias retomadas como uma cópia. ${ }^{97} \mathrm{~A}$ memória simples, ela mesma, não saberia ser puramente passiva, mesmo se ela não fosse ordenada pela reminiscência. De um lado, ela depende sempre do princípio orgânico interno que constitui o coração, ao mesmo tempo motor dos movimentos internos e sede da faculdade sensível primeira. ${ }^{98}$ Por outro lado, como toda atualização de uma faculdade da alma, ela não pode ser receptora sem ser igualmente, em um sentido, o agente dessa recepção" ${ }^{99}$.

Aristóteles vai então bem além de uma descrição do processo de conservação e de atualização da lembrança. Ele insere a memória no quadro das operações cognitivas e revela assim sua função na passagem da sensação aos atos de intelecção. Ele mostra igualmente, concebendo-a como uma atividade comum à alma e ao corpo, que a memória e o uso particular daquela que constitui a reminiscência desempenham um papel decisivo na constituição do caráter. Compreendemos assim porque Aristóteles insiste sobre o fato que a reminiscência é um hábito: porque ela resulta, mais seguidamente, de exercícios repetidos, ela produz uma habilidade adquirida e uma espontaneidade comparável àquela dos processos naturais. Como a

\footnotetext{
${ }^{95}$ De Mem., 1, 449 b 25; 2, 451 a 23, para apenas citar os casos nos quais não se trata manifestamente de de exis no sentido de "possessão".

${ }^{96}$ Eth. Nic., III, 7, 1114 b 1-3.

${ }_{97}$ De Mem., 1, 451 a 12-14.

${ }_{98}^{8}$ Sobre o coração - ou sua região - como "princípio" do conjunto dos movimentos internos nos animais sanguíneos, ver especialmente os capítulos 8 a 11 do De Motu (Do movimentos dos animais). 0 capítulo 11 do De Motu mostra, além disto, que o coração tem uma função, irredutível, de transmissão dos movimentos às outras partes, e isso não somente nos movimentos voluntários (como no adormecer ou no acordar), ou involuntários (como a pulsação ou a ereção). Ver precisamente sobre esse ponto MOREL, P.-M. "Volontaire, involontaire et non volontaire dans le chapitre 11 du "De Motu de Aristote". In: em LAKS, A.; RASCHED, M. (eds.). Aristote et le mouvement des animaux.. Dix études sur le "De Motu animalium". Villeneuve d'Ascq: Presses du Septentrion, 2004, p. 167-183.

${ }_{99}$ Aristóteles se opõe, assim, a respeito da sensação, às explicações que a assimilam a uma pura passividade. Ver De An., II, 5, 417 a 14-20.
} 
disposição para a virtude, ou como a ciência do sábio, em oposição a simples aptidão universal dos ignorantes para adquirir a ciência ${ }^{100}$ ela inclina à rememoração segundo uma ordem determinada. Como as virtudes morais, ela desenha certos traços do caráter individual. A relação entre o exercício metódico da memória e a aquisição das virtudes não é explicitamente examinado por Aristóteles. Talvez porque esteja embaraçado pela convergência dos dois processos de habituação e de memorização. A reminiscência, por seu lado, não está de nenhuma maneira reservada ao exercício da deliberação moral. Além disso, a aquisição dos hábitos não é necessariamente um trabalho consciente e deliberado, sobretudo quando ela começa desde a infância e que se realiza sob o efeito da educação moral, cujo sujeito, por definição, não a controla. Há, entretanto, uma clara homologia entre, de um lado, a maneira pela qual o agente moral delibera e decide, se apoiando sobre as disposições adquiridas cujas as condições originais lhe escapam parcialmente, e de outra parte, uma memória que nasce, se desenvolve e se exerce em se misturando à lembrança consciente, e controla as partes de sombra da história pessoal.

A perspectiva psicofísica adotada por Aristóteles mostra aqui toda sua fecundidade. De um lado, ela fornece uma explicação da formação e das disfunções da memória. De outro lado, ela mostra que sua incorporação, porque permite a conservação das imagens e habituação mental, longe de ser um obstáculo à continuidade da experiência pessoal, é a condição primeira dela. Ela permite enfim de entrever como o homem pode ser o agente e o organizador de seus próprios pensamentos.

${ }^{100}$ De An., II, 5, 417 a 22-b 2. 


\section{Referências bibliográficas}

\section{Textos}

Carbone, A. Aristotele. L'anima e il corpo (Parva naturalia), Milano, 2002. King, R. A. H. Aristoteles. De Memoria et reminiscentia, E. Grumach et H. Flashar, Aristoteles Werke in Deutscher Übersetzung, Band 14, Teil II, Berlin: Akademie Verlag, 2004.

Morel, P.-M. Aristote, Petits traités d'histoire naturelle (Parva naturalia). Paris: GF Flammarion, 2000.

Mugnier, R. Petits traités d'histoire naturelle, texte établi et traduit. Paris: Les Belles Lettres, 1953.

Natali, C. Aristotele. Etica Nicomachea. Roma-Bari: Laterza, 1999.

Ross, D. Aristotle. Parva naturalia, a revised Text with Introduction and Commentary. Oxford: Clarendon Press, 1955.

Ross, G. R. T. Aristotle. De Sensu and De Memoria, Text and Translation with Introduction and Commentary. Cambridge, 1906.

Siwek, P. Parva naturalia Graece et Latine, Edidit, versione auxit, notis illustravit P. S., coll. "Philosophica Lateranensis” 5, Desclée, Roma, 1963.

Sorabji, R. Aristotle. On Memory. London: Duckworth, 1972

Veloso, C. Aristóteles. Da Lembrança e da Rememoração. De Memória et Reminiscentia. Cadernos de História e Filosofia da ciência, Série 3, v. 12, n. especial, jan.-dez. 2002.

\section{Estudos}

Annas, J. "Aristotle on memory and the self". In: NUSSBAUM, M. C.; RORTY A. O. (éd.), Essays on Aristotle's De Anima. Oxford: Clarendon Press, 1992, p. 297-311.

Barnes, J.; Schofield M.; Sorabji R. (eds). Articles on Aristotle, IV: Psychology and Aesthetics. London, Duckworth, 1977.

Di Martino, C. 'La memoria nell'Epitome dei Parva naturalia di Ibn Rushd”. In: CRISCIANI, C.; LAMBERTINI; R.; MARTORELLI, V. (eds.), Parva naturalia. Saperi medievali, natura e vita. Pisa-Roma, 2004, p. 189199. 
Dixsaut, M. "Une certaine espèce de vie (Philèbe, 34 D 1 - 36 C 3)”. In M. Dixsaut (ed.). La Fêlure du plaisir. Études sur le Philèbe de Platon. Paris: Vrin, 1999, p. 245-265.

Everson, S. Aristotle on Perception. Oxford: Clarendon Press, 1997.

Labarrière, J.-L. "Jamais l'âme ne pense sans phantasme”. In: MOREL, P.M. (ed.). Aristote et la notion de nature. Enjeux épistémologiques et pratiques. Bordeaux: PUB, 1997, p. 149-179.

. "Sentir le temps, regarder un tableau. Aristote et les images de la mémoire”. In: DARBO-PESCHANSKI, C. (ed.), Constructions du temps dans le monde grec ancien. Paris: CNRS Éditions, 2000, p. 269-283.

LLoyd, G. E. R.; Owen, G. E. L. (éd.), Aristotle on Mind and the Senses. Proceedings of the Seventh Symposium Aristotelicum. Cambridge, 1978.

Modrak D.K.W. Aristotle. The Power of Perception. Chicago-London: The University of Chicago Press, 1987.

Morel P.-M. “L'habitude, une seconde nature ?”. In: MOREL, P.-M. (ed.). Aristote et la notion de nature. Enjeux épistémologiques et pratiques. Bordeaux, PUB, 1997, p. 131-148.

. Aristote. Une philosophie de l'activité, Paris: GF Flammarion,

2003.

. "Volontaire, involontaire et non volontaire dans le chapitre $11 \mathrm{du}$ De motu d'Aristote”. In: LAKS, A.; RASHED, M. (eds.). Aristote et le mouvement des animaux. Dix études sur le De motu animalium. Villeneuve d'Ascq: Presses du Septentrion, 2004, p. 167-183.

Morel, P.-M. (ed.). Aristote et la notion de nature. Enjeux épistémologiques et pratiques. Bordeaux: PUB, 1997.

Natali C. La saggezza di Aristotele. Napoli: Bibliopolis, 1989.

Nussbaum M. C. et Rorty A. O. (eds.) Essays on Aristotle's De Anima. Oxford: Clarendon, 1992.

Romeyer Dherbey G. (ed.). Corps et âme. Sur le De Anima d'Aristote. Études réunies par Cristina Viano. Paris: Vrin, 1996.

Taormina D. "Perception du temps et mémoire chez Aristote (De memoria et reminiscentia, 1)". Philosophie antique, 2, 2002, p. 33-61.

Van der Eijk, Ph. "The Matter of Mind: Aristotle on the Biology of 'Psychic' Processes and the Bodily Aspects of Thinking”. In: KULLMANN, W.; FÖLlingER, S. (ed.). Aristotelische Biologie. Intentionen, Methoden, Ergebnisse. "Philosophie der Antike", Band 6. Stuttgart, 1997, p. 231-258. 
Waterlow, S. Nature, Change and Agency in Aristotle's Physics. Oxford: Oxford University Press, 1982.

Wedin, M. V. Mind and Imagination in Aristotle. New Haven-London: Yale University Press, 1988.

Wiesner, J. "Gedächtnis und Denkobjekte. Beobachtungen zu Mem. 1, 449b30-450a14”. In: WIESNER, J. (ed.). Aristoteles Werk und Wirkung, Paul Moraux gewidmet, t. 1: Berlin-New York: Walter de Gruyter, 1985, p. 168190.

E-mail: pierremarie.morel@gmail.com

Recebido: setembro/2009

Aprovado: outubro/2009 